\title{
Poligami dari Perspektif Kepastian Hukum dan Keadilan
}

\author{
Ady Irawan ${ }^{1, *}$ \\ ${ }^{1}$ STKIP Taman Siswa Bima \\ 1adyirawan652@gmail.com \\ *Coresponding Author
}

\begin{tabular}{|c|c|}
\hline Artikel Info & Abstrak \\
\hline$\underline{\text { Tanggal Publikasi }}$ & Poligami merupakan salah satu fenomena sosial yang muncul ditengah \\
\hline 2019-06-30 & $\begin{array}{l}\text { kehidupan bermasyarakat dan bernegara Indonesia. Berbicara masalah ini, } \\
\text { selalu diwarnai oleh kontroversi, baik itu dari aspek kepastian hukum dan }\end{array}$ \\
\hline$\underline{\text { Kata Kunci }}$ & keadilan. Kedua hal ini tidak selalu seiring sejalan, belum tentu kepastian \\
\hline Poligami & $\begin{array}{l}\text { hukum akan melahirkan keadilan begitu pula sebaliknya, belum tentu sesuatu } \\
\text { yang dirasa adil akan memenuhi unsur kepastian hukum. Penelitian ini }\end{array}$ \\
\hline Kepastian Hukum & bertujuan untuk mengetahui poligami baik dari perspektif kepastian hukum di \\
\hline Keadilan & $\begin{array}{l}\text { Indonesia dan dari perspektif keadilan hukum. Jenis penelitian ini adalah } \\
\text { penelitian doktrinal dengan pendekatan deskriptif kualitatif. Data diperoleh } \\
\text { melalui studi kepustakaan (library research) dan diolah secara komprehensif } \\
\text { melalui pendekatan yuridis empiris. }\end{array}$ \\
\hline
\end{tabular}

\section{PENDAHULUAN}

Setiap manusia mempunyai kepentingan yang merupakan suatu tuntutan perorangan atau kelompok yang diharapkan untuk dipenuhi. Sejak kecil beranjak dewasa serta menjelang saat ia meninggal dunia kepentingannya berkembang (Sudikno Mertokusumo, 2005 : 1). Manusia akan berusaha menjaga kelangsungan hidupnya dan berupaya agar keturunannya bisa tetap survive dalam hidupnya. Salah satu dari sekian banyak cara yang bisa ditempuh demi terlaksananya tujuan tersebut adalah melalui apa yang kita kenal dengan istilah perkawinan. Dalam Islam, hal ini di atur dalam AlQur'an Surat Ar-Rum ayat 21 (QS. 30 : 21).

Dalam konteks bernegara Indonesia, beberapa regulasi mengatur tentang pernikahan. Sebelum lahirnya Undang-undang Nomor 1 Tahun 1974 Tentang Perkawinan, Burgerlijk Wetboek (BW) atau lazim dikenal sebagai Kitab Undang-Undang Hukum Perdata (KUH Perdata) peninggalan Kolonial Belanda. Dalam Pasal 26 BW mendefinisikan perkawinan yakni pertalian yang sah antara seorang lelaki dan seorang perempuan untuk waktu yang lama. Pasal ini memandang perkawinan hanya dari hubungan keperdataan saja, tidak lebih.

Menurut Subekti, Pasal 26 BW tersebut hendak menyatakan bahwa suatu perkawinan yang sah, hanyalah perkawinan yang memenuhi syarat-syarat yang ditetapkan dalam KUH Perdata dan syaratsyarat serta peraturan agama dikesampingkan. Suatu asas lagi dalam KUH Perdata, ialah poligami dilarang. Larangan ini termasuk ketertiban umum, artinya bila dilanggar selalu diancam dengan pembatalan perkawinan yang dilangsungkan itu (Subekti, 2003 : 23).

Apa yang diuraikan dalam Bergerlijk Wetboek yang memandang bahwa perkawinan hanya sebatas urusan keperdataan saja, jelas tidak sejalan dengan nilai Ketimuran yang melekat dan identik dengan bangsa Indonesia, apalagi ditambah bahwa mayoritas penduduk bangsa Indonesia adalah beragama Islam, yang notabene memandang bahwa perkawinan adalah merupakan ibadah. Hal inilah yang mendorong lahirnya Undang-Undang Nomor 1 Tahun 1974 Tentang Perkawinan, yang dengan begitu artinya mementahkan pengertian perkawinan sebagaimana yang diungkapkan oleh KUH Perdata diatas (lex specialis derogate lex generalis). 
Menurut Undang-Undang Nomor 1 Tahun 1974 Tentang Perkawinan Pasal 1 menyatakan, perkawinan yaitu ikatan lahir batin antara seorang pria dengan seorang wanita sebagai suami isteri dengan tujuan membentuk keluarga (rumah tangga) yang bahagia dan kekal berdasarkan Ketuhanan Yang Maha Esa.

Selanjutnya, Undang-undang Nomor 1 Tahun 1974 Tentang Perkawinan sendiri dalam Pasal 2 ayat (1) dan ayat (2) telah meregulasikan bahwa perkawinan dikatakan sah apabila memenuhi dua unsur, yakni : (a) Apabila dilakukan menurut hukum masing-masing agamanya dan kepercayaannya. (b) Tiap-tiap perkawinan dicatat menurut peraturan perundang-undangan yang berlaku

Berdasarkan hal di atas, dapat dikatakan bahwa Perkawinan di Indonesia ini sah apabila memenuhi dua unsur, pertama dilakukan berdasarkan agama dan kepercayaan yang di anut dan kedua adalah harus tercatat oleh lembaga yang berwenang yang ditunjuk untuk itu. Kedua hal tersebut harus dipenuhi secara komprehensif, tidak parsial. Artinya, kedua syarat tersebut harus terpenuhi semua dan bukan salah satunya saja yang terpenuhi.

Seiring dengan makin berkembanganya kehidupan masyarakat dewasa ini, sering kali kita melihat fenomena yang terjadi dalam kehidupan masyarakat Indonesia seperti adanya perkawinan poligami, perkawinan poliandri, perkawinan siri, perkawinan beda agama, serta perkawinan kontrak. Lahirnya jenis-jenis perkawinan tersebut, sebenarnya tidak terlepas dari kondisi masyarakat kita yang semakin plural, tidak kuasa membendung hegemoni modernisasi yang cenderung tidak terkontrol, serta berbagai tekanan serta tuntutan hidup yang semakin mahal dewasa ini. Semuanya itu bermuara pada tujuan manusia agar tetap survive.

Banyaknya jenis perkawinan sebagaimana tersebut di atas, jelas menimbulkan polemik ditengah masyarakat. Banyak pro dan kontra muncul dalam menanggapi masalah ini, tentunya dengan berbagai argumentasi yang dikedepankan masing-masing pihak, mulai dari segi kepastian hukum dari sebuah perkawinan hingga masalah keadilan. Masalah kepastian hukum memang menarik untuk dikaji mengingat Indonesia merupakan negara hukum. Tak bisa kita pungkiri pula, bahwa dalam realita yang terjadi, antara kepastian hukum dan keadilan sering kali terjadi disharmoni antara keduanya, karena belum tentu apa yang kita kenal dengan hukum, mencerminkan nilai keadilan, khususnya keadilan dalam perspektif Islam.

Mengingat akhir-akhir ini sering kali diperdebatkan oleh publik masalah poligami, baik dalam berbagai seminar maupun dalam media-media online, cetak, serta elektronik, maka kajian ini lebih memfokuskan pada hal tersebut, yang terkristalisasi dari judul Poligami Dari Perspektif Kepastian Hukum dan Keadilan.

Penelitian ini bertujuan untuk : (1) Mengetahui poligami dari perspektif kepastian hukum di Indonesia; (2) Mengetahui poligami dari perspektif keadilan dalam hukum Islam

\section{METODE PENELITIAN}

Penelitian ini menggunakan metode kualitatif bersifat deskriptif bertujuan memberikan gambaran yang jelas, objektif, sistematis, dan cermat mengenai fakta-fakta yang diperoleh dari objek yang ditelaah, yang dalam hal ini adalah terkait Poligami dari perspektif hukum positif Indonesia dan hukum Islam serta dari konsep keadilan

\subsection{Sumber Data}

Berdasar jenis penelitian di atas, sumber data dalam penelitian ini adalah seperti dokumendokumen resmi, buku-buku yang berhubungan dengan objek penelitian, hasil penelitian dalam bentuk laporan, dan peraturan perundang-undangan, data ini dapat dibagi menjadi: a) Sumber data primer; b) sumber data sekunder; c) Sumber data Tersier 


\subsection{Teknik Pengumpulan Data}

Pengumpulan data dalam penelitian ini dilakukan melalui Studi Kepustakaan (library research). Diperoleh melalui penelitian kepustakaan yang bersumber dari Peraturan Perundang-undangan, buku-buku dokumen resmi, publikasi, dan hasil penelitian, khususnya yang terkait poligami dan konsep keadilan dalam Islam.

\subsection{Teknik Analisis Data}

Penelitian ini menggunakan analisis data deskriptif kualitatif, komprehensif, dan lengkap. Analisis kualitatif adalah menguraikan data dalam bentuk kalimat yang teratur, runtun, logis, tidak tumpang tindih dan efektif sehingga memudahkan interpretasi data dan pemahaman hasil analisis. Komprehensif berarti analisis data secara mendalam dari berbagai aspek sesuai dengan lingkup penelitian. Sedangkan lengkap artinya tidak ada bagian yang terlewatkan, kesemuanya sudah masuk dalam analisis.

\section{HASIL DAN PEMBAHASAN}

\subsection{Fenomena Poligami}

Permasalahan poligami dewasa ini semakin bertambah rumit karena banyak terdapat pertentangan oleh berbagai pihak dalam menyetujui diperbolehkannya dilakukan poligami yang berupa diperketatnya persyaratan pelaksanaan poligami.

Poligami sendiri mempunyai arti suatu sistem perkawinan antara satu orang pria dengan lebih dari seorang istri. Pada dasarnya dalam Undang-Undang Perkawinan Nomor 1 Tahun 1974 menganut adanya asas monogami dalam perkawinan. Hal ini disebut dengan tegas dalam Pasal 3 Ayat (1) yang menyebutkan bahwa pada asasnya seorang pria hanya boleh mempunyai seorang istri dan seorang wanita hanya boleh mempunyai seorang suami. Akan tetapi asas monogami dalam UndangUndang Perkawinan tidak bersifat mutlak, artinya hanya bersifat pengarahan pada pembentukan perkawinan monogami dengan jalan mempersulit dan mempersempit penggunaan lembaga poligami dan bukan menghapus sama sekali sistem poligami. Ini dapat diambil sebuah argumen yaitu jika perkawinan poligami ini dipermudah maka setiap laki-laki yang sudah beristri maupun yang belum tentu akan beramai-ramai untuk melakukan poligami dan ini tentunya akan sangat merugikan pihak perempuan juga anak-anak yang dilahirkannya nanti dikemudian hari (Lailatul Mardhiyah : 2010)

Muhammad Daud Ali menyatakan, bahwa beristri lebih dari seorang merupakan jalan darurat yang baru boleh dilalui oleh seorang laki-laki Muslim kalau terjadi bahaya, antara lain ; untuk menyelamatkan dirinya dari berbuat dosa, kalau, istrinya misalnya, tidak mampu memenuhi kewajibannya sebagai istri (Muhammad Daud Ali, 2005 : 139).

Lebih lanjut beliau mengatakan, dalam ikatan perkawinan sebagai salah satu bentuk perjanjian (suci) antara seorang pria dengan seorang wanita yang mempunyai segi-segi perdata, berlaku beberapa asas diantaranya adalah : (a) Kesukarelaan, (b) Persetujuan kedua belah pihak, (c) Kebebasan memilih, (d) Kemitraan suami-istri, (e) Untuk selama-lamanya, dan (e) Monogami terbuka (karena darurat).

Diantara asas-asas yang dikemukakan diatas, yang paling menarik perhatian publik dewasa ini adalah asas yang keenam, yakni monogami terbuka.

Menurut Muhammad Daud Ali, asas monogami terbuka disimpulkan dari Al-Quran surat AnNisa (4) Ayat (3) jo Ayat (129). Surat An-Nisa Ayat (3) yang artinya : "Dan jika kamu takut tidak akan dapat Berlaku adil terhadap (hak-hak) perempuan yang yatim (bilamana kamu mengawininya), Maka kawinilah wanita-wanita (lain) yang kamu senangi : dua, tiga atau empat. kemudian jika kamu takut tidak akan dapat Berlaku adil, Maka (kawinilah) seorang saja, atau budak-budak yang kamu miliki. yang demikian itu adalah lebih dekat kepada tidak berbuat aniaya" 
Dalam Ayat (129) Surat An-Nisa Allah berfirman yang artinya : "Dan kamu sekali-kali tidak akan dapat Berlaku adil di antara isteri-isteri(mu), walaupun kamu sangat ingin berbuat demikian, karena itu janganlah kamu terlalu cenderung (kepada yang kamu cintai), sehingga kamu biarkan yang lain terkatungkatung. dan jika kamu Mengadakan perbaikan dan memelihara diri (dari kecurangan), Maka Sesungguhnya Allah Maha Pengampun lagi Maha Penyayang"

\subsection{Kepastian Hukum Poligami di Indonesia}

Sebagai sebuah negara hukum, Indonesia memandang unsur kepastian hukum (asas Legalitas) sangat diperlukan dalam segala hal, terutama aspek yang diatur oleh negara yang dalam hal ini termasuk perkawinan poligami. Sebab tanpa adanya unsur tersebut, maka status Indonesia sebagai negara hukum patut dipertanyakan, walaupun pada kenyataannya sering kali kita jumpai bahwa kepastian hukum ini bersebelahan dengan keadilan.

Undang-undang No. 1 Tahun 1974 Tentang Perkawinan, meregulasikan bahwa perkawinan itu adalah sah apabila memenuhi unsur dalam Pasal 2 sebagaimana disebutkan sebelumnya. Selain itu mengenal istilah poligami, dimana sebelum menuju ke arah perkawinan tersebut seorang suami harus melalui jalan yang tidak mudah, hal itu semata-mata demi melindungi kepentingan istri dan anakanak yang kemungkinan akan terabaikan bila seorang suami melakukan poligami.

Dalam kasus poligami, adapun syarat utama yang harus dipenuhi adalah suami mampu berlaku adil terhadap istri-istrinya dan anak-anaknya, akan tetapi jika si suami tidak bisa memenuhi maka suami dilarang beristri lebih dari satu, disamping itu si suami harus terlebih dahulu mendapat ijin dari Pengadilan Agama (bagi Muslim) dan Pengadilan Negeri (bagi Non-Muslim), jika tanpa ijin tersebut maka perkawinan tersebut tidak mempunyai kekuatan hukum.

Pengadilan Agama/Pengadilan Negeri baru dapat memberikan ijin kepada suami untuk berpoligami apabila ada alasan yang tercantum dalam Pasal 4 Ayat (2) UU Perkawinan Nomor 1 tahun 1974 : (1). Istri tidak dapat menjalankan kewajiban sebagai istri. (2) Istri mendapat cacat badan atau penyakit yang tidak dapat disembuhkan. (3). Istri tidak dapat melahirkan keturunan

Disamping syarat-syarat tersebut yang merupakan alasan untuk dapat mengajukan poligami juga harus dipenuhi syarat-syarat pendukung yaitu : (1). Adanya persetujuan dari istri. (2). Ada kepastian bahwa suami mampu menjamin keperluan hidup istri dan anak-anaknya. (3). Ada jaminan bahwa suami berlaku adil terhadap para istri dan anak-anaknya.

Khusus untuk Pegawai Negeri Sipil (PNS) yang hendak berpoligami, syarat-syaratnya diatur dalam dalam Peraturan Pemerintah Nomor 10 tahun 1983 sebagaimana diubah dalam Peraturan Pemerintah Nomor 45 Tahun 1990. Aturan poligami bagi PNS ini secara eksplisit di atur dalam Pasal 4, yaitu sebagai berikut : (1). Pegawai Negeri Sipil pria yang akan beristri lebih dari seorang, wajib memperoleh izin lebih dahulu dari Pejabat. (2). Pegawai Negeri Sipil wanita tidak diizinkan untuk menjadi istri kedua/ketiga/keempat. (3). Permintaan izin sebagaimana dimaksud dalam ayat (1) diajukan secara tertulis. (4) Dalam surat permintaan izin sebagaimana dimaksud dalam ayat (3), harus dicantumkan alasan yang lengkap yang mendasari permintaan izin untuk beristri lebih dari seorang.

\subsection{Keadilan Dalam Konsep Islam.}

Abdul Ghofur Anshori mengatakan, dalam pandangan filsafat, tujuan akhir hukum adalah keadilan, dimana keadilan itu harus mengacu pada pedoman pokok agama Islam yakni Al-Quran dan Hadist. Artinya tujuan keadilan melalui jalur hukum harus berawal dari dua segi dan mengarah pada keadilan dua segi pula.

Lebih lanjut beliau mengatakan, maksud dari muara keadilan dua segi adalah tujuan akhir berupa keadilan yang harus dicapai oleh sebuah sistem hukum universal mesti berorientasi pada keadilan terhadap manusia (makhluk) dan keadilan kepada Allah (Khaliq) 
Masih menurut beliau, keadilan dalam Islam merupakan perpaduan harmonis antara hukum dengan moralitas, Islam tidak bertujuan untuk menghancurkan kebebasan individu, tetapi mengontrol kebebasan itu demi keselarasan dan harmonisasi masyarakat yang terdiri dari individu itu sendiri. Hukum Islam memiliki peran dalam mendamaikan pribadi dengan kepentingan kolektif, bukan sebaliknya. Individu diberi hak untuk mengembangkan hak pribadinya dengan syarat tidak mengganggu kepentingan orang banyak (Abdul Ghofur Anshori, 2005 : 153)

Salah satu konsep penting dan fundamental yang menjadi pokok bahasan dalam filasafat hukum Islam adalah konsep maqasid at-tasyri' atau maqasid al-syariah yang menegaskan bahwa hukum Islam disyari'atkan untuk mewujudkan dan memelihara maslahat umat manusia. Konsep ini telah diakui oleh para ulama dan oleh karena itu mereka memformulasikan suatu kaidah yang cukup populer,"Di mana ada maslahat, di sana terdapat hukum Allah." Teori maslahat di sini menurut Masdar F. Masudi sama dengan teori keadilan sosial dalam istilah filsafat hukum. (Ahmad Zaenal Fanani, 2010).

Adapun inti dari konsep maqasid al-syariah adalah untuk mewujudkan kebaikan sekaligus menghindarkan keburukan atau menarik manfaat dan menolak mudarat, istilah yang sepadan dengan inti dari maqasid al-syari'ah tersebut adalah maslahat, karena penetapan hukum dalam Islam harus bermuara kepada maslahat. (Ahmad Zaenal Fanani, 2010).

\subsection{Makna Keadilan Dalam Konsep Poligami}

Kasus-kasus poligami yang kebanyakan terjadi saat ini jika ditinjau dari perspektif keadilan sangat sulit sekali terpenuhi, dimana walaupun suami tersebut mampu dalam segi materiilnya tetapi belum mampu dalam segi moril dalam pembagian terhadap istri-istrinya. Sehingga dalam hal ini masih diperlukan pemikiran lebih dalam lagi serta pertimbangan-pertimbangan yang lebih matang dalam pengambilan sikap suatu tindakan. (Lailatul Mardhiyah, 2010).

Imam Syafi'i, as-Sarakhsi dan al-Kasani mensyaratkan keadilan diantara para istri, menurut mereka keadilan ini hanya menyangkut urusan fisik semisal mengunjungi istri di malam atau di siang hari (Khoiruddin Nasution, 1996 : 103). Sementara itu, Abdurrahman Doi mengatakan seorang suami yang hendak berpoligami menurut ulama fiqh paling tidak memliki dua syarat : Pertama, kemampuan dana yang cukup untuk membiayai berbagai keperluan dengan bertambahnya istri. Kedua, harus memperlakukan semua istrinya dengan adil. Tiap istri harus diperlakukan sama dalam memenuhi hak perkawinan serta hak-hak lain. (Abdurahman Doi, 2002 : 192).

Muhammad Husein al-Zahabi mendefinisikan adil sebagai adanya persamaan dalam memberikan nafkah dan pembagian hari terhadap sesama istri dalam batas yang mampu dilakukan oleh manusia. Mustafa al-Siba'i mengatakan bahwa keadilan yang diperlukan dalam poligami adalah keadilan material seperti yang berkenaan dengan tempat tinggal, pakaian, makanan, minum, perumahan dan hal-hal yang bersifat kebutuhan material istri.

Berbagai pendapat diatas, para ulama fiqh cenderung memahami keadilan secara kuantitatif yang bisa diukur dengan angka-angka. Muhamad Abduh berpandangan lain, keadilan yang disyaratkan al-Qur'an adalah keadilan yang bersifat kualitatif seperti kasih sayang, cinta, perhatian yang semuanya tidak bisa diukur dengan angka-angka. Hal ini sebagaimana termaktub dalam AlQur'an yang artinya : "Jika kamu sekalian khawatir tidak bisa berlaku adil, maka kawinilah satu isrti saja"(QS. $4: 3$ ).

Muhammad Abduh menjelaskan, apabila seorang laki-laki tidak mampu memberikan hak-hak istrinya, rusaklah struktur rumah tangga dan terjadilah kekacauan dalam kehidupan rumah tangga tersebut. Sejatinya, tiang utama dalam mengatur kehidupan rumah tangga adalah adanya kesatuan dan saling menyayangi antar anggota keluarga 
Mayoritas ulama fiqh (ahli hukum Islam) menyadari bahwa keadilan kualitatif adalah sesuatu yang sangat mustahil bisa diwujudkan. Abdurrahman al-Jaziri menuliskan bahwa mempersamakan hak atas kebutuhan seksual dan kasih sayang di antara istri-istri yang dikawini bukanlah kewajiban bagi orang yang berpoligami karena sebagai manusia, orang tidak akan mampu berbuat adil dalam membagi kasih sayang dan kasih sayang itu sebenarnya sangat naluriah. Sesuatu yang wajar jika seorang suami hanya tertarik pada salah seorang istrinya melebihi yang lain dan hal yang semacam ini merupakan sesuatu yang di luar batas kontrol manusia (Harun, 2010).

M. Quraish Shihab menafsirkan makna adil yang disyaratkan oleh Ayat (3) Surat An-Nisa' bagi suami yang hendak berpoligami adalah keadilan dalam bidang material. Sebagaimana yang ditegaskan oleh Surat An-Nisa' Ayat (4) : "Kamu sekali-kali tidak akan dapat berlaku adil di antara isteri-isterimu, walaupun kamu sangat ingin berbuat demikian, karena itu janganlah kamu terlalu senderung (kepada yang kamu cintai), sehingga kamu biarkan yang lain terkatung-katung" (QS. 4:4)

Masih menurut beliau, keadilan yang dimaksudkan dalam ayat diatas adalah adil dalam bidang immaterial (cinta). Keadilan ini yang tidak mungkin dicapai oleh kemampuan manusia. Oleh sebab itu suami yang berpoligami dituntut tidak memperturutkan hawa nafsu dan berkelebihan cenderung kepada yang dicintai. Dengan demikian, tidaklah tepat menjadikan ayat ini sebagai dalih untuk menutup rapat pintu poligami. (M. Quraish Shihab, 1999 : 201).

Berdasarkan berbagai penafsiran ulama tentang makna adil dalam perkawinan poligami, dapatlah dirumuskan bahwa keadilan sebagai syarat poligami dalam perkawinan pada hal-hal yang bersifat material dan terukur. Hal ini menjadikan lebih mudah dilakukan dan poligami menjadi sesuatu lembaga yang bisa dijalankan. Sebaliknya, jika keadilan hanya ditekankan pada hal-hal yang kualitatif (immateriil) seperti cinta, kasih sayang, maka poligami itu sendiri menjadi suatu yang tidak mungkin dilaksanakan. Padahal Allah SWT menjanjikan dalam Al-Qur'an Surat Al-Baqarah ayat 286: "Allah tidak membebani seseorang melainkan sesuai dengan kesanggupannya" (QS. 2 : 286)

\section{KESIMPULAN}

Berdasarkan pada elaborasi hasil penelitian dan pembahasan di atas, maka dapat disimpulkan hal-hal sebagai berikut :

Poligami dari perspektif hukum Indonesia, pada dasarnya tidak memiliki ruang untuk diimplementasikan, mengingat Undang-Undang Nomor 1 Tahun 1974 Tentang Perkawinan menganut asas monogami. Namun, hal tersebut tidak berlaku secara kaku. Terdapat beberapa kondisi tertentu yang menyebabkan seorang suami bisa melakukan praktik poligami ini, yaitu dikategorikan ke dalam faktor utama dan beberapa faktor pendukung lainnya. Hal ini sebagaimana tertuang dalam Pasal 4 Ayat (2) Undang-Undang Nomor 1 Tahun 1974. Untuk kategori Pegawai Negeri Sipil (PNS/ASN), syarat poligami ini diatur lebih lanjut pada Peraturan Pemerintah Nomor 10 Tahun 1983 sebagaimana diubah dalam Peraturan Pemerintah Nomor 45 Tahun 1990.

Poligami ditinjau dari perspektif keadilan dalam Islam, mewajibkan seorang suami berlaku adil, sebagaimana amanat Al-Qur'an Surat An-Nisa Ayat (4). Adapun konsep keadilan yang dimaksud adalah keadilan yang bersifat materiil yang dapat diukur seperti pemenuhan sandang, pangan, dan kebutuhan lainnya. Dalam hal ini, keadilan yang dimaksud adalah bukan keadilan yang bersifat kualitatif (immaterial) seperti cinta dan kasih sayang, karena keadilan seperti ini diluar kemampuan manusia, karena manusia cenderung mengikuti hawa nafsunya dengan melebihkan cinta dan kasih sayangnya kepada salah satu dari istrinya sebagaimana Firman Allah SWT dalam Surat An-Nisa Ayat (129). 


\section{Daftar Pustaka}

Al-Qur'an

Abdul Ghofur Anshori. (2005). Filsafat Hukum Kewarisan Islam. Yogyakarta: UII Press.

Abdurahman Doi. (2002). Penjelasan Lengkap Hukum-Hukum Allah (Syari'ah). Jakarta: Rajawali Press.

Ahmad Zaenal Fanani, Teori Keadilan Dalam Perspektif Filsafat Hukum dan Isalam, dalam Http//www : pta-banjarmasin.go.id/index.php? content=mod_artikel\&id=29, tanggal 6-Juli 2010, jam 00.45 WITA.

Harun, Keadilan Dalam Perkawinan Poligami Perspektif Hukum Islam (Aspek Sosiologis Yuridis), dalah Http//www: hksuyarto.wordpress.com/2008/05/26, tanggal 7 Juli 2010, Jam 00.20 WITA.

Khoiruddin Nasution. (1996). Riba dan Poligami; Sebuah Studi atas Pemikiran Muhammad Abduh. Jakarta: Pustaka Pelajar.

Lailatul Mardhiyah, Poligami Ditinjau Dari Hukum Positif, dalam Http//www : Unisys.uii.ac.id/index.asp? $\mathrm{u}=131 \& b=1 \& v=1 \& \mathrm{j}=1 \& \mathrm{~d}=6$, Tanggal 6-Juli-2010, Jam 00.15 WITA.

Muhammad Daud Ali. (2005). Hukum Islam; pengantar ilmu hukum dan tata hukum Islam di Indonesia. edisi 6. Jakarta: RajaGrafindo Persada.

M. Quraish Shihab. (1999). Wawasan al-Qur'an. Bandung: Mizan.

Peraturan Pemerintah Nomor 10 Tahun 1983 sebagaimana diubah dengan Peraturan Pemerintah Nomor 45 Tahun 1990.

Sudikno Mertokusumo. (2005). Mengenal Hukum; Suatu Pengantar. edisi ke 5. Yogyakarta: Liberty.

Subekti. (2003). Pokok-Pokok Hukum Perdata, ctk ke-31. Jakarta: PT Intermasa.

Undang-Undang Nomor 1 Tahun 1974 Tentang Perkawinan. 